\title{
EXTRATIVISMO DO BUTIÁ NO MUNICÍPIO DE TAPES/RS: CONSERVAÇÃO E USO COMO ALTERNATIVA PARA O DESENVOLVIMENTO RURAL SUSTENTÁVEL
}

\author{
BUTIÁ EXTRATIVISM IN THE MUNICIPALITY OF TAPES/RS: CONSERVATION \\ AND USE AS AN ALTERNATIVE FOR SUSTAINABLE RURAL DEVELOPMENT
}

\author{
João Luis Silva CAMPOS JUNIOR ${ }^{1 *}$; Rafaela Biehl PRINTES ${ }^{2}$
}

${ }^{1}$ Gestor Ambiental. Universidade Estadual do Rio Grande do Sul, Unidade em Tapes, *camposjr.bga @ gmail.com; ${ }^{2}$ Geógrafa. Dra. em Desenvolvimento Rural. Professora da Universidade Estadual do Rio Grande do Sul, Unidade em Tapes.

\section{RESUMO}

Submitted: 28/07/2020; Accepted: 19/09/2020

Desde 2017, a Universidade Estadual do Rio Grande do Sul, Unidade de Tapes, é instituição parceira da Rota Internacional dos Butiazais, projeto coordenado pela Embrapa Clima Temperado que conecta pessoas e promove uma rede de estímulos voltados à conservação in situ e uso sustentável da palmeira do gênero Butia em locais de ocorrência. Neste estudo, buscou-se identificar os extrativistas e artesãos envolvidos diretamente com a Rota, mapear as áreas de coleta da matéria-prima e registrar o preparo de alimentos e objetos produzidos com o uso da fibra, folhas, sementes e frutos. A área de estudo foi o município de Tapes, localizado às margens da planície costeira do Rio Grande do Sul (RS). Entre Tapes e Barra do Ribeiro, encontra-se o maior butiazal do Brasil, um ecossistema único que carece de práticas que conduzam ao manejo e conservação da espécie. Destaca-se o extrativismo de folhas e frutos da palmeira B. odorata em Tapes, pela diversidade de produtos e alimentos encontrados em épocas de frutificação. Trata-se de uma pesquisa descritiva, de natureza qualitativa-quantitativa, com uso de método Snowball sampling e técnicas de entrevistas semiestruturadas, observação participante e mapeamento participativo das coletas realizadas como instrumento da análise de campo. Foram identificados dez extrativistas e artesãos pertencentes à Associação dos Produtores da Agricultura Familiar de Tapes (APAFTAPES), onde eles promovem o aprendizado, sendo multiplicadores de saberes, e comercializam seus objetos e alimentos a partir da matéria-prima coletada. Estas e outras ações asseguram o uso desse fruto pela conservação de espécies nativas e fortalecimento da Rota em Tapes, resultando, inclusive, na incorporação da polpa de butiá na merenda escolar do município através do Programa Nacional de Aquisição de Alimentação Escolar (PNAE) e promoção de eventos locais anuais, como a $1^{\mathrm{a}}, 2^{\mathrm{a}}$ e $3^{\mathrm{a}}$ Semana de Atividades Sobre o Uso Sustentável do Butiá realizada desde 2018.

Palavras-chave: butiazal, espécies nativas, manejo, sociobiodiversidade, sustentabilidade.

\section{ABSTRACT}

Since 2017, UERGS (Universidade Estadual do Rio Grande do Sul) is a partner insitution in "The Butiazais' Route in the Pampa Biome", a Project coordinated by Embrapa Clima Temperado that connects people and promotes a net of stimulous towards in situ conservation and sustainable use of a native Palm tree of the genus Butia in places of occurrrence. In this study, it was sought to identify extractivists, craftsman and craftswomen directly envolved with the Route, to map areas of collection of raw material for food preparation and for objects production using the fiber, leaves, seeds and fruits. The study area is in Tapes, located on the coast of flat land edges of Rio Grande do Sul. Between Tapes and Barra do Ribeiro is found the largest butiazal of Brazil, a unique ecosystem that lacks practices to allow management and conservation of the species. The extractivism of the leaves and fruits of the palm tree $B$. odorata in Tapes is highlighted by the various handcraft products and food made with the fruit pulp. This research made use of the Snowball sampling method and as well a qualitative and semi structured interviews, participant observation, monitoring extractivism activities. There were identified 10 (ten) extractivists/craftspeople in Tapes, being part of the Family Farming Producers Association of Tapes (APAFTAPES), where they sell their products and promote learning as knowledge multipliers. The promoted actions by extractivists/craftspeople and farmers involved, contribute to fortify the Butiazais' Route, including results on the incorporation of the butia fruit in the school meals of the city through the National Program of Acquisition of School Food (PNAE) and in the $1^{\text {st }}, 2^{\text {nd }}$ and $3^{\text {rd }}$ Week of Activities on the Sustainable Use of Butiá.

Keywords: butiazal, native species, handle, sociobiodiversity, sustainability. 


\section{INTRODUÇÃO}

Esta pesquisa considerou o extrativismo da palmeira Butia odorata (B. odorata) como uma alternativa para o desenvolvimento rural sustentável na região Centro Sul do estado do Rio Grande do Sul. No município de Tapes, a área de estudo deste trabalho, a palmeira B. odorata permanece em ameaça de extinção em consequência de fatores como a ausência de manejo na pecuária tradicional que inviabiliza a regeneração e conservação in situ dos butiazais, pois as novas plântulas são consumidas durante o pastejo do gado, e demais atividades agrícolas que os substituem para monoculturas de arroz, soja, pinus e eucalipto (MARCHI; BARBIERI; SOSINSKI, 2019).

Nesta região do Bioma Pampa, encontra-se o maior butiazal do Brasil e registra-se também um ciclo econômico de extrativismo das folhas da palmeira em meados da década de 1970 . Nesta década, a produção de crina vegetal extraída da folha do butiazeiro para o enchimento de colchões e móveis estofados manteve a economia local, porém, com o avanço da indústria petroquímica, essas fibras foram substituídas por fibras sintéticas. Além disso, com a agricultura mecanizada e a expansão de áreas urbanas, a espécie chegou ao ápice de sua resiliência, pois os habitats que antigamente mantinham a palmeira nos ecossistemas da região foram drasticamente reduzidos e/ou modificados (BARBIERI, 2017). Ao encerrar o ciclo econômico da crina vegetal, os butiazeiros foram esquecidos e, só recentemente, passaram a chamar atenção e serem revalorizados pelos moradores e produtores rurais como parte da biodiversidade do Pampa e pela sua importância histórico-cultural, envolvendo a troca de saberes e a conservação pelo uso de espécies nativas. Soma-se ao contexto, que atualmente os alimentos da sociobiodiversidade são reconhecidos e valorizados no âmbito das políticas públicas de segurança alimentar e nutricional no Brasil, como o Programa Nacional para Alimentação Escolar (PNAE), o Programa de Aquisição de Alimentos (PAA) e a Política de Garantia de Preços Mínimos para os Produtos da Sociobiodiversidade - PGPMBio, que promovem a proteção da biodiversidade em seus biomas juntamente com a diversidade cultural que realiza o manejo das espécies, desde o cultivo ao preparo dos alimentos. A portaria interministerial $n^{\circ} 163 / 2016$, em seu art. $1^{\circ}$, listou "com base em espécies nativas da flora brasileira, as espécies consideradas da sociobiodiversidade, para fins de comercialização in natura ou de seus produtos derivados", estando no âmbito destas políticas públicas o $B$. catarinenses e B. eriospatha entre estas espécies, por exemplo (BRASIL, 2016).

O município de Tapes abrange uma área de $80.4091 \mathrm{~km}^{2}$ e uma população de 16.629 habitantes, conforme Censo (IBGE, 2010). Apesar de ser um ecossistema fragilizado, o butiazal abriga inúmeras espécies de fauna e flora ameaçadas de extinção. Somente em uma das propriedades rurais de Tapes estão preservadas mais de 70.000 palmeiras B. odorata, ocupando aproximadamente 800 hectares (GEYMONAT; ROCHA, 2009; SOSINSKI, et al., 2015). Desse modo, estes espaços têm ganhado cada vez mais visibilidade na região através de pesquisas e atividades que promovam a sua gestão, bem como a prática extrativista local que passa a revalorizar a palmeira $B$. odorata como parte integrante da sociobiodiversidade pelos moradores. Este movimento está associado à rede da Rota Internacional dos Butiazais, criada a partir do projeto coordenado pela Embrapa Clima Temperado intitulado "A Rota dos Butiazais no Bioma Pampa: conectando pessoas e ecossistemas para a conservação e o uso sustentável da biodiversidade" (CNPq Processo 441493/2017-3), que tem como objetivo de "contribuir para garantir a segurança alimentar, hídrica e energética no Bioma Pampa, através da conservação e uso sustentável da biodiversidade em territórios com ecossistemas de butiazais" (BARBIERI, 2017 p. 13). Além dos estados do Rio Grande do Sul e Santa Catarina, o projeto reuniu parceiros no Uruguai e Argentina. No Brasil, conta com a parceria de instituições de extensão rural, estimulando a troca de experiências entre os atores rurais, de meio ambiente e universidades como a UERGS, UFRGS, UFPel e Unisinos, que promovem a pesquisa junto aos agricultores e extrativistas locais em busca de um modelo de desenvolvimento rural que contribua para a conservação destes ecossistemas de forma participativa, considerando os "aspectos sociais, culturais, ambientais e econômicos" (BARBIERI, 2017, p. 05). Estas ações têm despertado na população o incentivo ao empreendedorismo e empoderamento em estratégias de conservação pelo uso desta espécie em Tapes, onde se encontra diversidade de 
alimentos elaborados com a polpa e artigos decorativos feitos com o uso da fibra, sementes e folhas.

É a partir da exposição e venda de alimentos e artigos decorativos confeccionados manualmente com matéria-prima da palmeira que alguns extrativistas e artesãos promovem o aprendizado local e repassam as técnicas utilizadas, além de resgatar memórias de infância, utilizando-as como um instrumento didático de transmissão de conhecimento e aprendizagem. Entretanto, pouco se sabia sobre quem eram as pessoas envolvidas diretamente com as atividades do extrativismo de butiá em Tapes; suas principais dificuldades de acesso à matériaprima; suas relações e os produtos confeccionados, sendo esta uma demanda necessária para melhor planejar ações de gestão entre estes atores.

Foi através da parceria entre Uergs, unidade de Tapes, junto ao projeto da Embrapa que deuse início a este estudo, em busca de contribuições documentadas para o fortalecimento da Rota Internacional dos Butiazais, voltada a promover a conservação da palmeira do gênero Butia por meio do desenvolvimento rural sustentável.

\section{PERCURSO METODOLÓGICO}

Esta é uma pesquisa descritiva, de natureza qualitativa-quantitativa que avaliou a situação dos extrativistas de butiá no município de Tapes, suas dificuldades, técnicas de manejo, hábitos e tendências (MARCONI; LAKATOS, 2010). Foi utilizado o método Snowball sampling (Bola de Neve) para identificar e caracterizar os extrativistas e artesãos locais. Este método consiste em fazer um contato inicial com um informante que possua as peculiaridades da pesquisa ou que possa indicar alguém com estas características. Então, pede-se que este indique um ou mais possíveis candidatos característicos do estudo, sendo este processo repetido a cada entrevista, formando assim uma cadeia de informantes (PENROD et al., 2003).

Foram utilizadas técnicas de entrevistas semiestruturadas, observação participante e mapeamento participativo das coletas realizadas como instrumento da análise de campo (MARCONI; LAKATOS, 2010), onde o pesquisador acompanhou à demandada dos participantes, sendo possível registrar as atividades desenvolvidas pelos extrativistas/artesãos que vivenciam e repassam experiências, sendo multiplicadores de saberes. Observou-se as técnicas de manejo; identificou-se os tipos de matéria-prima utilizada e seu aproveitamento, bem como, as áreas de coletas que distribuem-se entre propriedades privadas e de livre acesso.

O mapeamento das áreas de coleta de folhas e frutos foi realizado com o uso de um aparelho GPS (Global Positioning System) Garmin Etrex 30x, onde marcou-se a posição geográfica dessas áreas para a elaboração de um mapa temático produzido através do programa de geoprocessamento ArcGis 10.5.

Foi utilizado também um gravador de voz para facilitar o registro completo das informações, estruturado após a decupagem dos áudios; caderno para anotações e câmera fotográfica.

Para a análise de dados foi utilizado o editor de planilhas Microsoft Excel 2010, no qual foram transformados os dados qualitativos em quantitativos, ou seja, separados por colunas da tabela o gênero dos extrativistas; os locais onde ocorreram as extrações de folhas e frutos e classificação enquanto da matéria-prima; classificação de objetos e alimentos, bem como os locais de comercialização.

Para classificar a matéria-prima da palmeira $B$. odorata e seus produtos, sejam alimentos e/ou objetos decorativos, foi utilizado o método de entrevista "semiestruturada", onde o entrevistador teve a liberdade de explorar amplamente com perguntas que puderam ser respondidas dentro de uma conversação informal (MARCONI; LAKATOS, 2010). Ainda por meio da "observação participante", foi possível registrar o preparo de cada alimento e objeto confeccionado diretamente pelos extrativistas e artesãos, utilizando-se de câmera fotográfica e gravador de voz para a coleta de depoimentos que foram agrupados desde a seleção e corte de folhas, frutos e sementes, até o produto final. Também foram identificados os pontos de vendas estratégicos destes produtos, bem como o interesse pela comercialização parcial dos frutos encontrados em grande quantidade no interior de propriedades rurais de Tapes, que vem sendo discutida por órgãos regulamentadores, como a Secretaria do Ambiente e Desenvolvimento Sustentável - SEMA, Prefeitura Municipal, Embrapa, Emater/Ascar, Uergs, produtores, 
extrativistas, artesãos e comunidade local. Cabe ressaltar que todas as informações inseridas neste estudo, igualmente o uso de imagens, foram consentidas pelos participantes, respeitando, assim, o parecer consubstanciado de número 2.602.847, aprovado pelo comitê de ética da Uergs em 16/04/2018.

\section{EXTRATIVISMO DE BUTIÁ E O DESENVOLVIMENTO RURAL EM TAPES}

Dentre os ciclos econômicos pelos quais passaram o município de Tapes, uma das principais atividades desenvolvidas teve relação direta com a palmeira do butiá. Na região composta por butiazeiros centenários, entre o final do século XIX e na primeira metade do século XX, era produzida a crina vegetal extraída das folhas da palmeira, servindo como base para $\mathrm{o}$ enchimento de colchões e estofados. Muitas propriedades rurais foram grandes produtoras da crina vegetal, que era vendida para outros Estados do Brasil, sendo esta a base econômica municipal do século XX (MUNHOZ, 2017; BARBIERI, 2015). No entanto, esta atividade entrou em decadência após o surgimento dos produtos derivados do petróleo, como os colchões de espuma. Apesar disso, muitos butiazeiros permaneceram em pé nas fazendas de Tapes, porém pressionados, em alguns casos manejados, em outros totalmente removidos para liberar espaço às atividades agrícolas, à silvicultura e à pecuária com pastejo e pisoteio intenso (PACHECO, 2017; ROSSATO; BARBIERI, 2007).

Localizados às margens da Lagoa dos Patos, os espaços rurais de Tapes se destacam pela biodiversidade e beleza cênica devido à especificidade dos ecossistemas locais, como a região dos butiazais que "compreende uma valiosa diversidade de flora e fauna nativa associada, onde ocorrem cadeias tróficas e fluxos de energia característicos da comunidade" (RIVAS; BARBIERI, 2014, p. 14). Como parte da biodiversidade brasileira o

Butiá é um gênero da palmeira (Aracaceae) que ocorre na América do Sul, cujas espécies se distribuem no Brasil, Paraguai, Uruguai e na Argentina. As populações naturais são conhecidas como butiazais ou palmares; as plantas são denominadas de butiazeiros ou de butiás; e os frutos são os butiás. No Brasil, ocorre no bioma Pampa, na Mata Atlântica e no Cerrado. No estado do Rio Grande do Sul são registradas oito espécies: Butia catarinensis, B. eriospatha, B. exilata, B. lallemantii, B. odorata, B. paraguayensis, B. witecrii e B. yatay (BARBIERI et at., 2016, p. 11).

É comum ver pessoas colhendo cachos de butiá em épocas de boas safras na região, pois, além de saboroso e nutritivo, o fruto também representa uma alternativa de renda extra para muitos extrativistas e artesãos locais que confeccionam objetos, alimentos e bebidas (BARBIERI et al., 2016). Segundo Grabher (2015), o território brasileiro era habitado por povos originários que extraiam da natureza parte da sua alimentação para sua subsistência, como os frutos, as madeiras, a caça e os remédios, sendo este o ciclo econômico marcado pela biodiversidade disponível e manejado de maneira sustentável. Quanto à prática do extrativismo sustentável, este "caracteriza-se por baixos investimentos de capital e pelo uso de tecnologias simplificadas, em que a mão de obra é o principal instrumento de extração, transporte e transformação do produto" (COELHO-DE-SOUZA, 2003, p. 19).

Com base no Sistema Nacional de Unidades de Conservação - SNUC (2000), a prática extrativista refere-se a um "sistema de exploração baseado na coleta e extração, de modo sustentável, de recursos naturais renováveis". Atualmente, apesar de haver o uso de espécies nativas na região, como da palmeira $B$. odorata, enquanto matéria-prima essencial à produção de artesanatos e iguarias, não espera-se efeitos negativos e/ou que comprometam a dinâmica destes ambientes, visto o baixo número de extrativistas identificados e coletas realizadas por safra, como também, por seguirem as recomendações de boas práticas de manejo para as atividades extrativistas (CAMPO-JUNIOR, 2018; RIVAS; BARBIERI, 2014). Desta forma, estas e outras práticas fortalecem uma cadeia de interesses voltados ao manejo sustentável dos recursos naturais e à valorização dos produtos da sociobiodiversidade promovida pela Rota 
Internacional dos Butiazais em parceria com a Uergs e demais instituições, considerando que o município possui uma das maiores concentrações do gênero Butia e de ecossistemas associados.

Nessa perspectiva, outras experiências no Brasil mostram que muitas famílias e comunidades vivem apenas da confecção e venda de artesanatos, como em Iporanga, no estado de São Paulo, em um dos Parques mais antigos do Estado, onde o trabalho manual predomina mediante o manejo de fibras vegetais florestais para a obtenção de recursos básicos à sobrevivência, seja para uso próprio, seja para o comércio (CORREIA et al., 2010). Em Tapes, parece que um dos problemas a ser enfrentado diariamente pelos extrativistas sejam os locais de livre acesso da matéria-prima, pois a maior concentração da palmeira está em propriedades privadas e a menor concentração em locais públicos, como vias/estradas secundárias que ligam os espaços periféricos do município. Nestes espaços, os butiazeiros estão vulneráveis, pois não há garantia de conservação pela comunidade, o que demanda ações de educação ambiental e conscientização para a maior proteção da palmeira em locais de livre acesso que contribui como alternativa de desenvolvimento rural territorial.

\section{DESENVOLVIMENTO RURAL SUSTENTÁVEL EM TAPES}

Em Tapes, a espécie $B$. odorata está ameaçada de extinção pela insensatez humana, que chegou a considerá-la "uma praga" nos campos após perder o "valor econômico", sendo substituída por monoculturas de pinus e eucalipto. Esta região seguiu se desenvolvendo sem práticas de manejo voltadas à conservação pelo uso do butiazeiro, fazendo-se necessário, para um melhor desempenho socioambiental das atividades rurais atuais a participação e o diálogo entre diferentes atores que integram o sistema sociopolítico e econômico, incluindo o agricultor familiar, pecuarista, os prestadores de serviço, artesãos, as comunidades ribeirinhas e quilombolas, tendo em vista a falta de políticas públicas eficientes que atendam as demandas de pessoas e comunidades.

É desafiante encorajar a sociedade a renovar sistemas produtivos por vezes insustentáveis, em meio aos padrões hegemonicamente já estabelecidos e constantemente executados, entretanto "a ruralidade, a territorialidade e o desenvolvimento sofrem tentativas de atualização e renovação", bem como os "domínios da política e o domínio das práticas sociais", que buscam novas referências do modo de agir e fazer (SCHNEIDER; MEDINA, 2009, p. 02).

Muito se pensa em crescimento e acúmulo de bens quando se fala em desenvolvimento, por certo destaca o conforto elevado, a prosperidade econômica, a busca incessante pelo bem-estar social e o consumo que se sobrepõem às dinâmicas territoriais, tendo como consequência a degradação parcial ou total dos ecossistemas. No Brasil, grande parte dos recursos econômicos está associada à exploração de seus ambientes naturais, o que exige medidas de proteção ambiental diante do impasse sustentável que tropeça no modelo de desenvolvimento. Almeida (2009, p. 41) observa que o "desenvolvimento nasce da compreensão da finitude dos recursos naturais e das injustiças sociais provocadas pelo modelo de desenvolvimento vigente na maioria dos países". Com o aumento desordenado das cidades, a expansão industrial, ampliação do comércio e o acúmulo de riquezas, fica ainda mais evidente o descaso e o desrespeito à vida em todas as suas formas. Manter um ambiente ecologicamente equilibrado e valorá-los pelos inúmeros serviços prestados parece ser adverso às necessidades humanas, quando orientadas a buscarem o dito "progresso" (ALMEIDA, 2009).

$\mathrm{Na}$ agricultura, por exemplo, este modelo, conhecido como de desenvolvimento, esteve diretamente ligado ao aumento da produtividade por meio de insumos químicos, o que provocou o engessamento dos setores de produção, enfraquecimento e esgotamento dos recursos naturais (ALMEIDA, 2009). Como uma prática voltada ao sustento das populações, o cultivo de alimentos sempre foi a principal relação entre o homem e a natureza, porém esta relação se perdeu devido à modernização da agricultura e de suas tecnologias em meados do século XX, quando o lucro ganhou força e eficiência econômica (DAL SOGLIO, 2013). Em Tapes, por exemplo, espécies da flora dos ecossistemas perderam seus espaços para as atividades agrícolas convencionais, como o cultivo de arroz e silvicultura, pela sua posição geográfica na planície costeira favorável a esses cultivos. Com isso, muitos butiazeiros foram dizimados, resultado de um modelo econômico marcado por grandes monoculturas e pela expansão de áreas urbanas. Este incentivo ao trabalho no campo, que envolve o uso intenso de defensivos agrícolas, 
tecnologias e de toda a cadeia produtiva interligada ao mercado externo, compromete a estabilidade dos ecossistemas locais, incluindo o do butiazal.

Almeida (2009, p. 36) considera que a noção de desenvolvimento envolve aspectos sociais, econômicos e culturais aplicados de maneira uniforme, não apenas associados à produção ou ao crescimento econômico, na qual se busca a modernização em padrões isolados, mas que compreenda a relação homem-natureza. Neste sentido, para Bertoldi; Maron, 2018, p. 05, a "biodiversidade assume, assim, uma fundamental importância, sendo que a economia e a sociedade são parceiros mais fracos, porquanto a biosfera pode existir sem os humanos, mas os humanos não podem existir sem ela". Esta reconstrução de valores prospera alternativas sustentáveis para o desenvolvimento local a partir da conservação de espécies da biodiversidade como os butiazeiros, visto as atividades do extrativismo, dentre outras ações em parcerias que fortalecem uma rede de troca de experiências que podem ser entendidas como a reciprocidade entre a cultura e a diversidade biológica e seus usos.

Tanto no município de Tapes, quanto em outros municípios da região Centro Sul, não existe uma agricultura diversificada que promova a valorização da biodiversidade em seus ecossistemas, com isso, consequentemente, a aplicação de agroquímicos utilizados coloca em risco a saúde das populações humanas e de todos os seres da flora e fauna, além de comprometer os recursos hídricos (BRASIL, [2008?]). Entretanto, as ações promovidas pela Rota dos Butiazais fortalecem atividades que contribuem para o desenvolvimento rural sustentável local, sob a lógica da agroecologia, assegurando a sociobiodiversidade e a segurança alimentar nutricional (SAN) através da gastronomia, artesanatos e turismo rural articulado junto aos produtores rurais da agricultura familiar, povos e comunidades tradicionais (COELHO-DESOUZA et al., 2018). Aos poucos, estes atores sociais consolidam uma rede protagonista em ações de governança essencial ao desenvolvimento territorial, considerando o equilíbrio entre os aspectos econômicos, sociais, culturais e ambientais a base da sustentabilidade.

\section{RESULTADOS E DISCUSSÕES}

Vincula-se este estudo à parceria entre UERGS, unidade de Tapes, e Embrapa Clima Temperado, com o objetivo de compor parte das informações relacionadas à conservação pelo uso sustentável da palmeira Butia e de promover o fortalecimento das ações em rede da Rota Internacional dos Butiazais no Bioma Pampa. A Rota dos Butiazais é composta por 21 municípios do Estado do Rio Grande do Sul, 04 municípios do Estado de Santa Catarina, 05 locais no Uruguai e 02 na Argentina (BARBIERI, 2017, p. 04) e mais recentemente áreas do Estado de Goiás e Minas Gerais foram integradas, conforme ilustra a Figura 01.

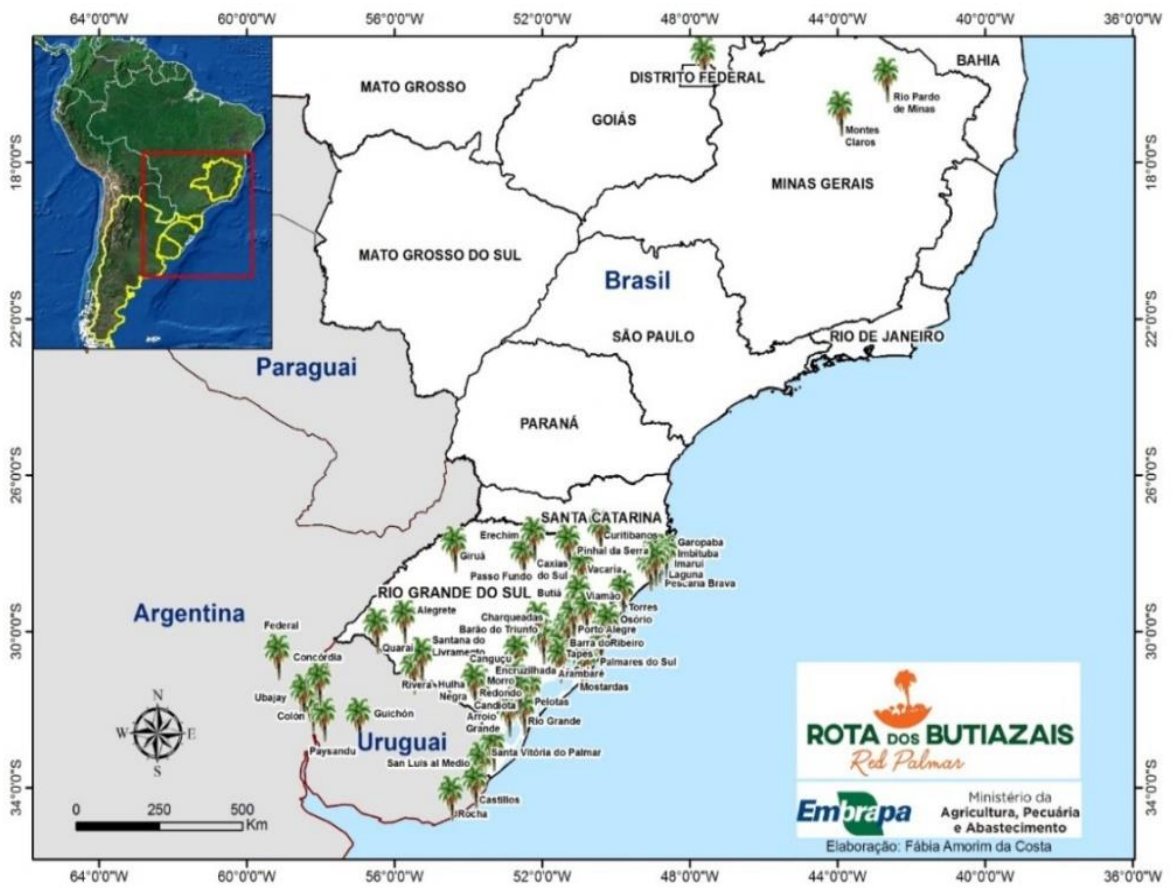

Figura 01: Mapa da Rota Internacional dos Butiazais (Fonte: EMBRAPA, 2020). 
A área de estudo foi o município de Tapes, integrante da Rota, localizado às margens da Lagoa dos Patos, na planície costeira do Estado do Rio Grande do Sul, que abriga a maior extensão de butiazais do Brasil (Figura 02).

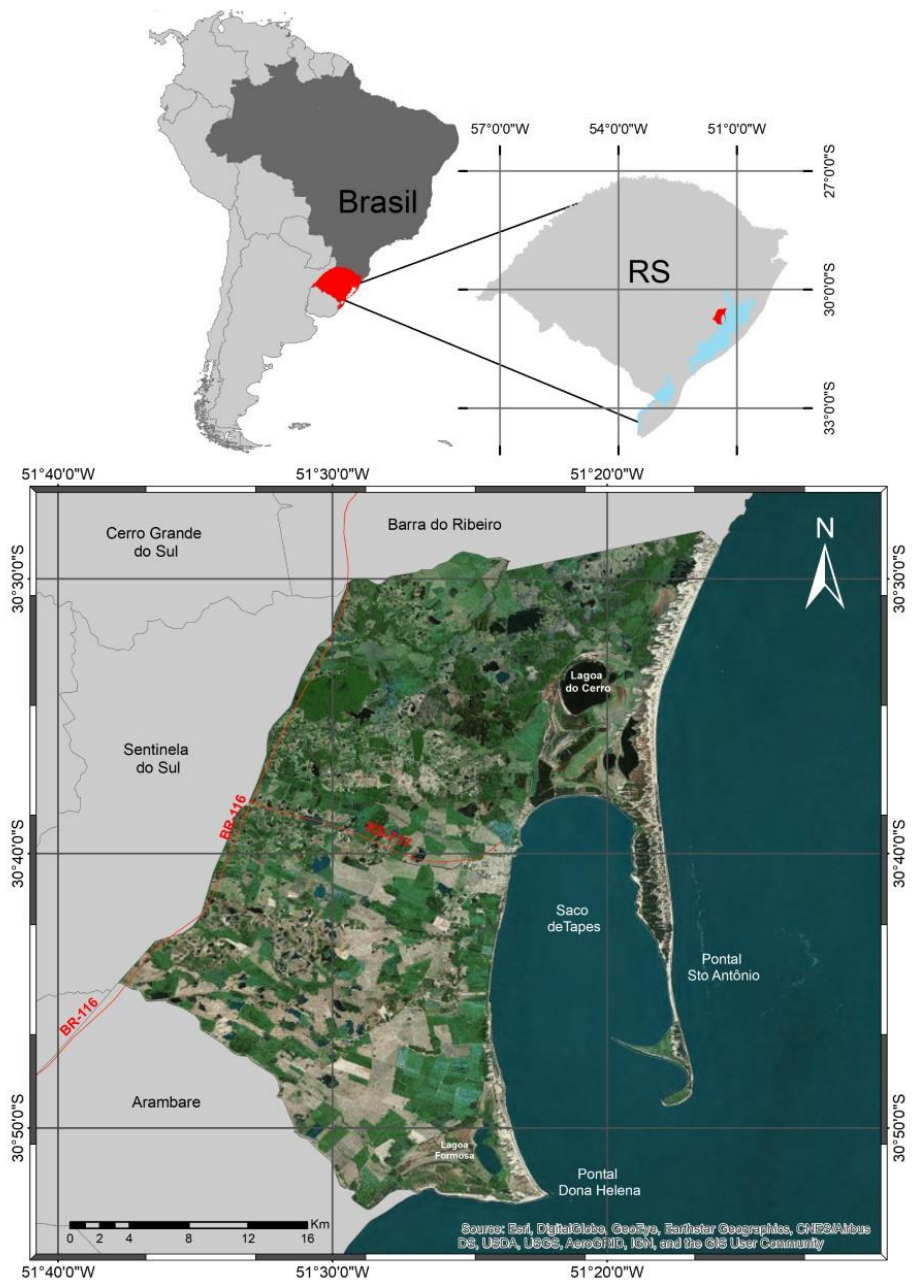

Figura 02: Localização geográfica da área de estudo (Fonte: SILVA, 2018).

Na região, as áreas são compostas por campos arenosos, dunas de areia, campos húmidos, banhados e matas brejosas, como também por extensas faixas destinadas à pecuária e ao cultivo agrícola. Entre Tapes e Barra do Ribeiro encontra-se a região dos butiazais, um ambiente natural que abriga diversidade de fauna e flora, situada a oeste da Laguna dos Patos (BECKER et al., 2006).

Este estudo analisou as ações promovidas pelo extrativismo local para melhor entender sobre como são feitas as coletas da matéria-prima, o beneficiamento da polpa para o preparo de alimentos, a confecção de peças artesanais, identificar os pontos de vendas e entender a relação entre a prática extrativista, considerada recente no município, com os ecossistemas da região e a promoção do desenvolvimento rural sustentável. Nesta amostra, foram identificados 10 participantes/extrativistas, 04 deles estavam desenvolvendo trabalhos artesanais, 03 deles apenas extraíam cachos de butiá, 01 deles se dedicava somente ao preparo de alimentos à base da polpa e 02 produziam, tanto artesanatos, quanto alguns alimentos. No entanto, foram identificados 02 jovens que tinham entre 11 e 14 anos de idade e que confeccionam artigos decorativos por meio de folhas. Todas as coletas foram acompanhadas de forma participativa e de acordo com a demanda dos extrativistas para registrar o manejo realizado, que não se difere entre eles, sendo os deslocamentos realizados em veículo particular. Esta logística contribuiu com o trabalho realizado por algumas extrativistas/artesãs que por vezes não desempenhavam suas atividades devido às limitações e dificuldades enfrentadas nos locais de coletas, visto que a 
aproximação entre o pesquisador e o público pesquisado foi de suma importância para que se construísse uma relação harmoniosa e de confiança, facilitando na realização das entrevistas, acompanhamento das ações desempenhadas e registros fotográficos.

Foi observada também, quanto à relação construída entre os extrativistas e artesãos, sobre a importância de manter práticas extrativistas/educativas no município, pois muitos deles se envolvem com o artesanato de forma ocupacional, sem atribuir preço aos seus produtos, mas apreço por cada peça produzida. Cerca de $70 \%$ dos participantes são mulheres, em sua maioria agricultoras; $55 \%$ delas coletam folhas, $36 \%$ delas coletam frutos e $9 \%$ delas aproveitam os coquinhos em volta dos butiazeiros para a confecção de artesanatos. Também, cerca de $67 \%$ da matéria-prima coletada é destinada à confecção de artesanatos e $33 \%$ à produção de alimentos. Com isso, do total de coletas, cerca de $57 \%$ foram registradas em propriedades de amigos, vizinhos e produtores pertencentes à associação.

A Figura 03 apresenta, em síntese, um gráfico que demonstra o cenário do extrativismo da palmeira butiá em Tapes, quanto aos atores sociais envolvidos, locais de coleta do recurso natural, às partes da matéria-prima manejada e aos espaços de comercialização.

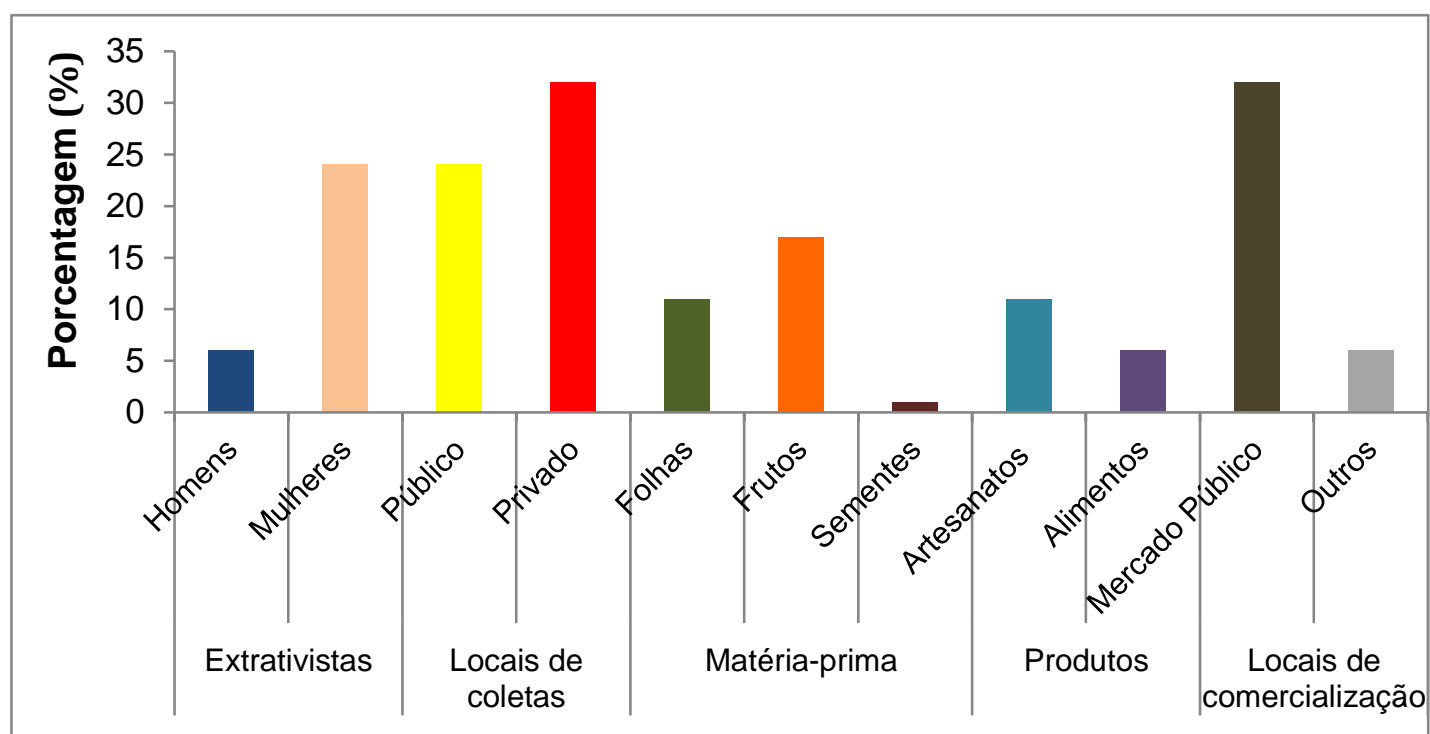

Figura 03: Distribuição percentual dos registros que caracterizam o cenário do extrativismo da palmeira $B$. odorata em Tapes (Fonte: AUTOR, 2020).

Todos os alimentos e objetos registrados neste estudo foram produzidos/confeccionados pelos próprios participantes. A procura pelas iguarias feitas à base da polpa de butiá cresceu no município em 2018, sendo destacado o suco como um dos alimentos de maior consumo, seguido de geleias, cucas, pães, salgados e doces. Grande parte das receitas e técnicas de preparo é destinada apenas a uma das participantes, que realiza suas coletas em propriedades de amigos e/ou em beiras de estradas. Outras duas participantes também aderem características próprias às receitas com o uso da polpa, inclusive de licores, porém em pequena quantidade e variedade devido às horas dedicadas aos diferentes artesanatos feitos com a fibra, com as sementes e com os folíolos.

Parte das coletas de folhas e frutos foi realizada em locais de livre acesso, principalmente na Estrada da Camélia e RS-717, que liga o município à BR-116 e demais vias públicas urbanas e rurais. Sabe-se também que alguns participantes realizam coletas em deslocamentos oportunos às cidades vizinhas e no interior do município de Sentinela do Sul.

O mapa abaixo (Figura 04) identifica a localização geográfica dos pontos de coleta da matéria-prima demandada pelos extrativistas em Tapes, classificando-os como locais de livre acesso e propriedades particulares. 


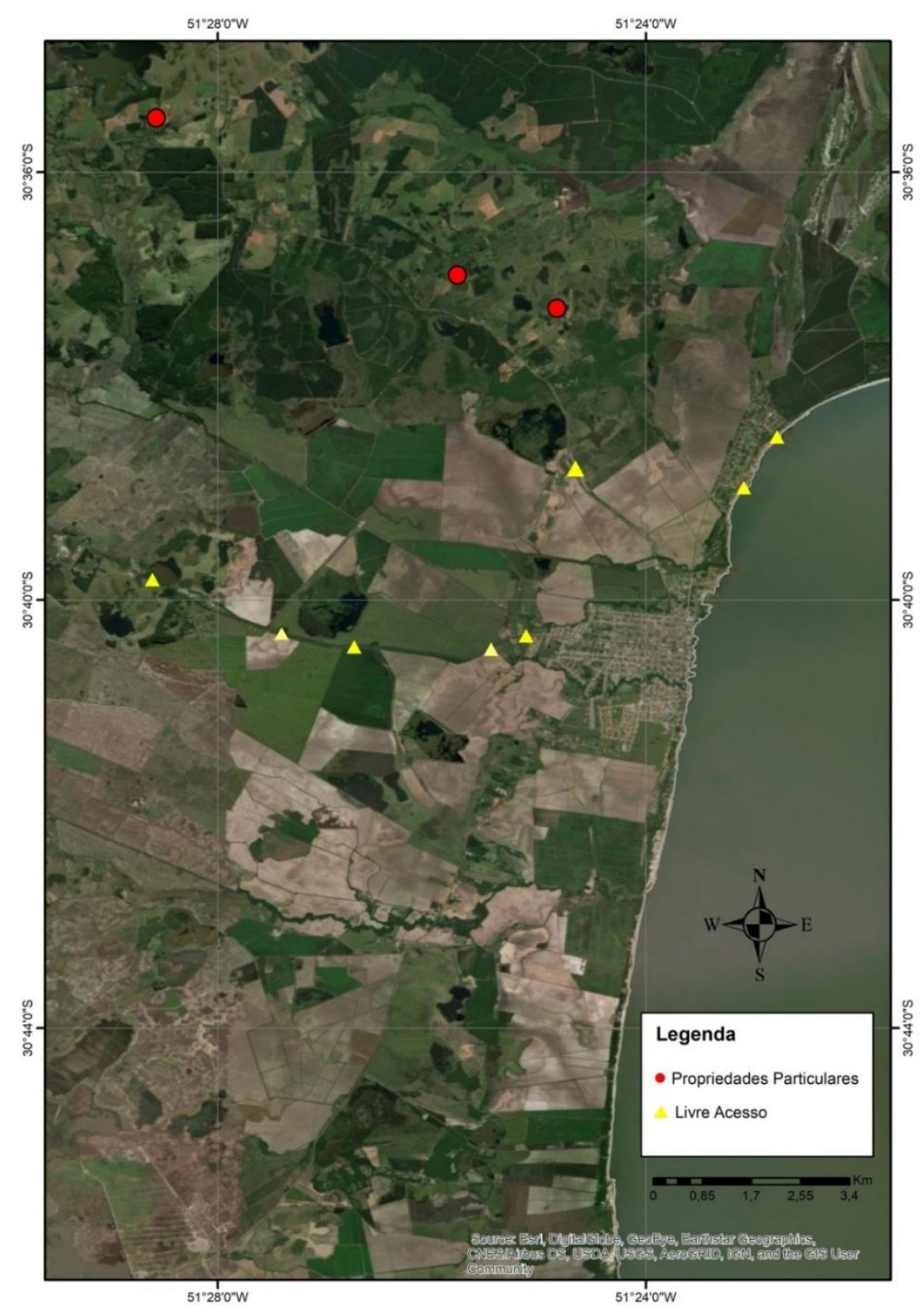

Figura 04: Localização geográfica dos pontos de coleta da matéria-prima em Tapes (Fonte: SILVA; CAMPOSJUNIOR, 2018).

Em Tapes, iniciou-se a produção de alimentos e artesanatos confeccionados a partir da matéria-prima do butiazeiro após uma viagem realizada pelas extrativistas-artesãs e produtores rurais da agricultura familiar à Feira do Butiá, no município de Giruá, no ano de 2016, onde parceiros como Embrapa e Emater organizaram deslocamentos e hospedagem. Antes disso, os participantes e a comunidade tapense pouco conheciam a diversidade de alimentos e produtos feitos com a matéria-prima, tampouco a importância da conservação pelo uso da palmeira em locais de ocorrência. Determinados a mudar a realidade da região, no que tange à valorização de espécies da biodiversidade local, como o butiá, uma das participantes incentivou a venda do suco e da polpa no mercado público da cidade, outras iniciaram as buscas por cursos de artesanatos para aprenderem a trabalhar com o uso da fibra, das folhas e sementes.

Em Tapes, as atividades, envolvendo a agricultura familiar, são incentivadas pela Emater/RS-Ascar que atua fortemente como instituição parceira das ações da APAFTAPES. O apoio de técnicos da Emater tem sido de fundamental importância para fortalecer a articulação dos extrativistas e artesãos na cidade desde o início do Projeto da Rota dos Butiazais. Entretanto, o empoderamento dos associados da APAFTAPES foi mencionado pelos técnicos 
da Emater que os acompanham, sobre cada vez mais conduzirem suas atividades autonomamente, organizando e realizando eventos como a $1^{\mathrm{a}}, 2^{\mathrm{a}}$ e $3^{\mathrm{a}}$ Semana de Atividades Sobre o Uso Sustentável do Butiá, promovidas pela associação em fevereiro de 2018, fevereiro de 2019 e março de 2020, respectivamente, em comemoração à colheita do fruto. Este evento, que passou a ser anual, reúne extrativistas, artesãos e produtores rurais de outros municípios que compõem a rede da Rota para trocarem experiências sobre feitios de artesanatos e receitas culinárias, além de promoverem o conhecimento histórico-cultural por meio de debates que regatam e dão visibilidade ao patrimônio material e imaterial associado à palmeira butiá. Para a realização das atividades, a associação procurou parcerias das instituições UERGS, Embrapa, Emater e Sicredi. Contudo, segundo informações e relatos dos colaboradores da APAFTAPES, a Prefeitura de Tapes não prestou apoio aos eventos, apesar de demandada pela associação, demonstrando o pouco interesse e reconhecimento das ações promovidas pela prática extrativista local.

A venda de alimentos e artesanatos de butiá complementa a renda de alguns extrativistas e artesãos, apesar de haver a falta de interesse da população por aquilo que é "local", o que inclui a valorização de produtos da sociobiodiversidade e do turismo rural. Desse modo, a venda e divulgação dos produtos feitos pelos artesãos se restringem em épocas de alta estação (verão) e feiras esporádicas em outros municípios do Centro Sul. O município de Tapes, por meio da Secretaria de Turismo, precisa ampliar sua oferta de entretenimento aos que veraneiam, não se restringindo somente à promoção do turismo náutico, à beleza cênica da Lagoa, mas voltando-se ao interior, dando opções aos visitantes. Não apenas para garantir alternativas de renda extra, como também, garantir um contato mais próximo dos ecossistemas locais, pois é assim que os participantes fortalecem cada vez mais a união em rede da Rota, repassando conhecimento e troca de experiências aos jovens tapenses por meio de ações voltadas à conservação pelo uso de espécies nativas.

Em um acompanhamento da confecção de objetos com o uso das folhas, os folíolos foram removidos e posteriormente fervidos durante $1 \mathrm{~h} 30 \mathrm{~min}$ em fogo baixo. Após esse processo, os folíolos são expostos à sombra para evitar o ressecamento extremado ao sol e não os comprometer, embora grande parte dos artesãos os hidratem com um pano umedecido. Após o processo de fervura, cada folíolo é amaciado individualmente com o dorso de uma faca ou tesoura para que os tornem maleáveis aos diferentes feitos de tramados ou trançados. Esta técnica foi registrada em apenas uma das poucas participantes que desenvolvem trabalhos com o uso de folhas. Apesar de ser uma prática recente no município, todos os extrativistas demonstram conhecimento quanto ao seu manejo para a obtenção da matéria-prima, sendo vetado o corte ao entorno da coroa e respeitado a coleta de, no máximo, 03 folhas por butiazeiro para que não comprometa o desenvolvimento da planta.

O fato de os participantes extraírem sua própria matéria-prima, para a confecção de objetos e/ou o preparo culinário, faz com que esta seja uma prática de pequena escala dentro e fora do município. Essas atividades aproximam pessoas de ecossistemas e contribuem com a proteção da diversidade de plantas, principalmente dos remanescentes de butiazeiros ameaçados de extinção e de animais que habitam as paisagens da região, visto que todos os entrevistados manifestam interesses em pesquisas e estudos envolvendo biossistemas locais, principalmente associados aos butiazeiros.

Algumas artesãs relatam serem surpreendidas em feiras e eventos à medida que os objetos expostos despertam olhares e curiosidade em cada detalhe, sobre cada peça. Outras relatam ter apego pelos primeiros trabalhos produzidos, mas ainda assim os levam para exposição no mercado público e em diversos eventos de artesanatos, encontros, cursos e feiras, porém não os comercializam. Cada um dos artesãos domina uma técnica específica, ou seja, alguns dominam a técnica do "feitio do anjo", tramado direto na folha do butiazeiro, outros dominam a técnica do artesanato com o uso da fibra, enquanto outros dominam técnicas com o uso de coquinhos e diferentes tipos de tramados e trançados.

Tendo em vista um conjunto de atividades voltadas ao desenvolvimento rural sustentável, cabe ressaltar que é recente o envolvimento da população local com as ações promovidas pela associação, no entanto, este movimento tem integrado diversos grupos sociais, como o produtor rural, os adolescentes, universitários e aposentados. Com isso, alguns participantes, inclusive os 
mirins, atuaram como oficineiros em projetos de extensão, nos quais buscaram estimular o conhecimento e a troca de experiências entre os alunos da rede pública municipal por meio de oficinas de artesanatos com o uso de folhas, fibra e sementes de butiá, sendo mais uma das atividades fortalecidas e estimuladas por práticas educativas de conservação.

Em 2018, durante o período de acompanhamento das atividades do extrativismo, a administração municipal acrescentou o fruto na merenda escolar de educação infantil para ser adquirido pelo Programa Nacional de Alimentação Escolar (PNAE). Os 200 quilos extraídos na safra de 2017/2018 foram parcialmente comprados por, pelo menos, uma das propriedades rurais locais, a qual mantém remanescentes de butiazeiros, visto a ação prevista na Lei 11.947 de 16 de junho de 2009, onde prevê que, do total dos recursos financeiros repassados pelo Fundo Nacional de Desenvolvimento da Educação (FNDE), no âmbito do PNAE, no mínimo $30 \%$ (trinta por cento) dos produtos alimentícios devem ser adquiridos da agricultura familiar e/ou do empreendedor familiar rural e de suas organizações.

No âmbito da rede da Rota dos Butiazais, cada um mantém presente sua contribuição, seja na prática extrativista, na confecção de produtos artesanais, no preparo de alimentos, no incentivo à conservação pelo uso, nas práticas empreendedoras, nos estudos e nas pesquisas. Diante das dificuldades e dos cortes de recursos financeiros, cabe ressaltar a importância da despolpadeira adquirida pela APAFTAPES, com recurso próprio da Emater, que contribui fortemente com todas as atividades envolvendo os usos do fruto. Destaca-se também a regularização dos extrativistas junto à Secretaria Estadual do Meio Ambiente e Infraestrutura (SEMA), pois todos demandam da Certificação Ambiental Agroflorestal e Extrativista para realizarem os manejos essenciais da palmeira do butiazeiro de acordo com legislação vigente, permitindo que o órgão responsável acompanhe e direcione todas as atividades do extrativismo sustentável em Tapes e demais municípios.

Segue abaixo um quadro ilustrativo de todos os produtos registrados pelos extrativistas e artesãos de acordo com a matéria-prima de origem (Quadro 01).

Quadro 01: Síntese dos produtos e matéria-prima de origem (Fonte: CAMPOS-JUNIOR, 2018).

\begin{tabular}{|l|l|}
\hline Matéria-prima & Produtos \\
\hline Fruto & $\begin{array}{l}\text { Bolos, cucas, salgados variados, mousse, sagu, sorvetes, geleias, sucos, licores e } \\
\text { compotas em calda. }\end{array}$ \\
\hline Folhas & $\begin{array}{l}\text { Anjos, arranjos, flores, cestarias, chaveiros, jogos americanos, tramados e/ou trançados } \\
\text { em copos, garrafas de licores, caixas de presentes e utensílios antigos. }\end{array}$ \\
\hline Sementes & $\begin{array}{l}\text { Enfeites em abajur, enfeites de bolos (amêndoa), enfeites para chimarrão e vasos de } \\
\text { flores. }\end{array}$ \\
\hline Fibra & Abajur, cachepots, enfeites em garrafas de licores, farinha e barquinhos decorativos. \\
\hline
\end{tabular}

Antes do corte, os cachos são ensacados para que não haja perda de fruto ao lançar a ferramenta (facão ou serrote) sobre a nervura da folha. Posteriormente, permanecem armazenados em sacos plásticos por um período de dois ou três dias ou até que conclua a fase de amadurecimento total dos frutos (Figura 05).

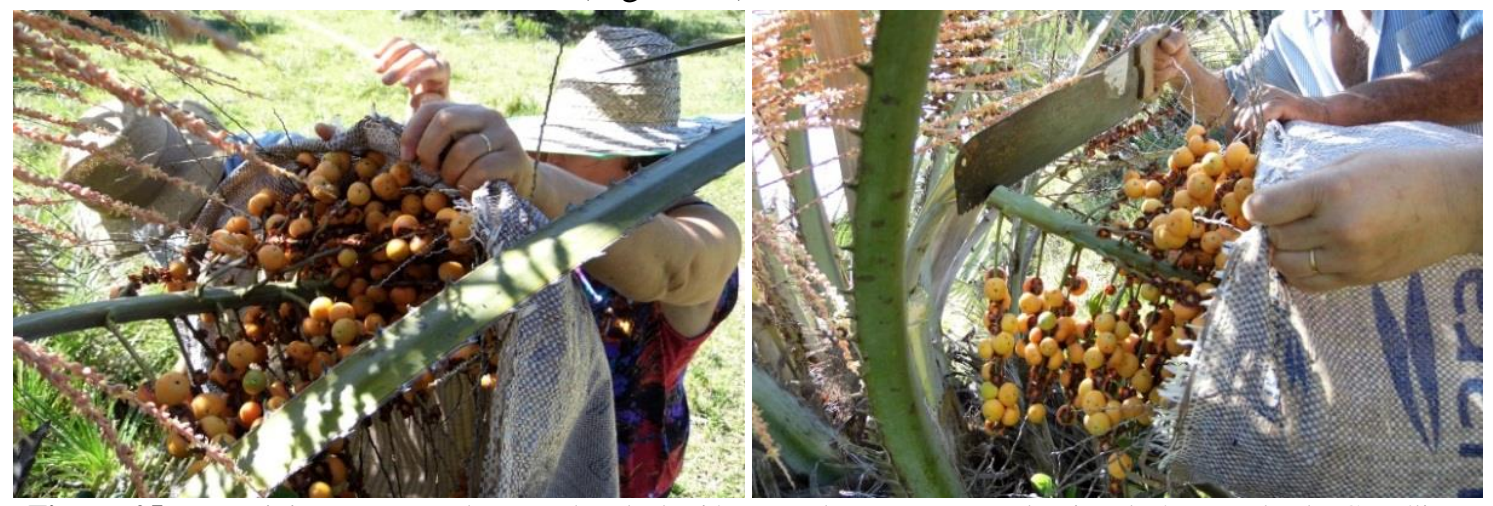

Figura 05: Extrativistas ensacando o cacho de butiá antes do corte. Fazenda situada à Estrada da Camélia, em Tapes/RS (Fonte: AUTOR, 2018). 
Há restrições quanto ao corte de cachos em palmeiras que atingem alturas elevadas, pois "os butiazeiros apresentam um caule do tipo estipe ${ }^{1}$, que pode atingir até 12 metros de altura e 60 cm de diâmetro", suas "folhas medem de 2 a 3 metros de comprimento e são pinaticompostas (Figura 06), isto é, possuem um eixo central” (RIVAS; BARBIERI, 2014, p. 17).

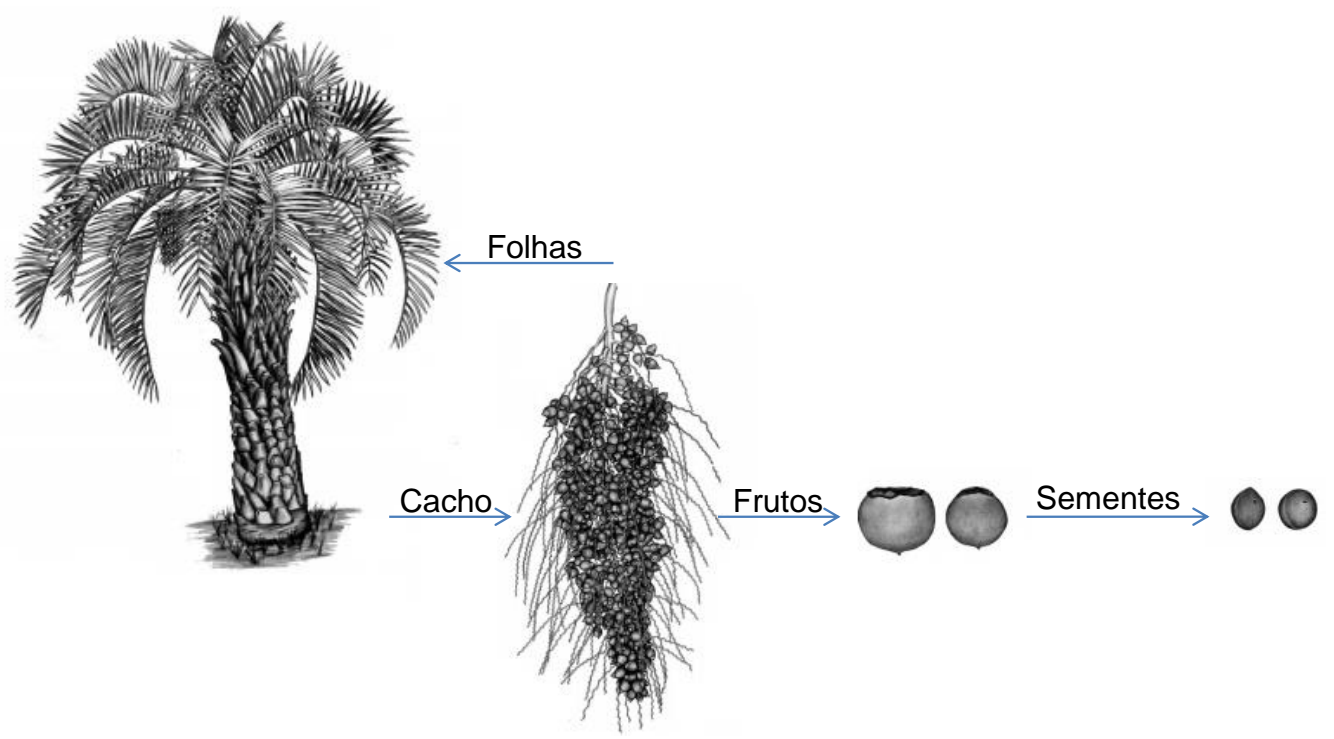

Figura 06: Ilustração da palmeira $B$. odorata enquanto matéria-prima demandada pelos extrativistas e artesãos (Fonte: Adaptado de SOARES et al., 2014).

Após concluir a fase de amadurecimento total dos cachos, inicia-se o processo de classificação e higiene dos frutos. Os butiás não destinados ao consumo são descartados em lugares estratégicos, como terrenos baldios, fundos de quintais, canteiros, acessos e estradas da zona rural, embora também sejam reaproveitados como complemento da alimentação de bovinos e suínos.

A polpa é a matéria-prima mais utilizada no preparo de alimentos, rendendo cerca de $50 \%$ do peso de um cacho, uma vez que a fibra e o tamanho do caroço mantenham volumes em determinada proporção. Os frutos podem ser armazenados de uma safra à outra, no entanto, após classificação e limpeza em água corrente, devem ser embalados em saquinhos plásticos ou despolpados e armazenados em garrafas resistentes a baixas temperaturas. O processo de despolpa pode ser feito de modo caseiro, adicionando apenas 01 copo de água em um liquidificador, porém, este exige alguns cuidados devido à consistência pastosa da fibra e à resistência do caroço, que pode comprometer a vida útil do aparelho no ato da liquidificação. Como consequência, após o caroço ser triturado por inteiro, introduz-se uma coloração escura à polpa, identificada pelas participantes como "resina", podendo comprometer a aparência dos alimentos e o aceite destes pelos clientes e feirantes.

A separação da polpa é feita em uma peneira, em uma pequena quantidade, o que torna mais eficiente a filtração da matéria em estado líquido. Do caroço é retirada a amêndoa, usada na decoração de bolos, cucas e biscoitos, como também é retirada a fibra testada na produção de farinha sem glúten e na confecção de artesanatos. Mesmo com a abundância de matéria-prima na região, há grandes chances de uma safra ser inferior às anteriores, isso acontece por causa das oscilações do número de cachos produzidos de um ano para o outro e por fatores climáticos (SCHWARTZ et al., 2009). Por este motivo, os frutos são mantidos congelados e armazenados em épocas de boas safras.

No Mercado Público de Tapes, os agricultores e artesãos fazem a despolpa do butiá com o auxílio de uma máquina despolpadeira própria. Este equipamento é constituido de pás que se movem com intensa velocidade para triturar o fruto, forçando-o a passar por uma peneira que separa a fibra e os caroços da polpa. A máquina foi comprada com recurso da Emater/RS-Ascar

\footnotetext{
${ }^{1}$ Estipe: Caules não ramificados que apresentam em seu ápice um tufo de folhas.
} 
de Tapes e é utilizada coletivamente pelos agricultores pertencentes à Associação dos Produtores e à população local. Quando o processo é concluído, percebe-se o início da quebradura das sementes, sendo este o momento certo para desligar o equipamento e para evitar que a "resina" não comprometa a estética da matéria-prima e/ou do produto final. Em seguida, a polpa é retirada, consumida e/ou embalada em garrafas pet higienizadas, o que viabiliza o armazenamento em pequenos refrigeradores (Figura 07).
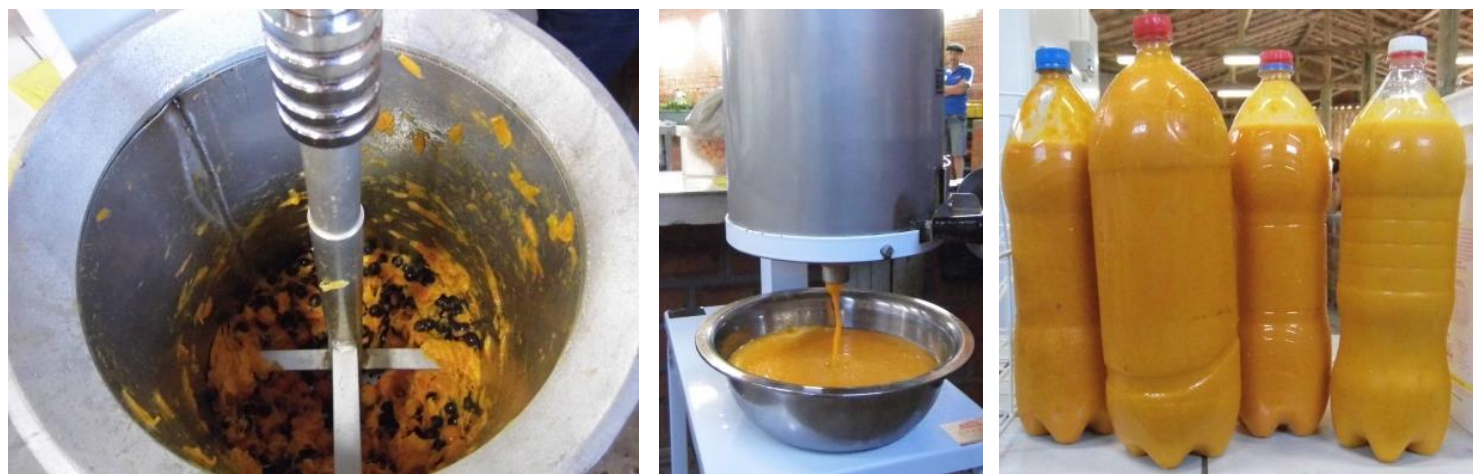

Figura 07: Despolpa de butiá realizada em equipamento adquirido pela APAFTAPES, separação e armazenamento (Fonte: AUTOR, 2018).

Segundo os extrativistas, há uma perda de aproximadamente $30 \%$ da polpa quando ocorre a despolpa de frutos congelados e/ou pouco maduros, visto à dificuldade de captação do alimento em estado líquido. A população tapense também faz o uso compartilhado do equipamento, devendo os interessados em utilizar o serviço levar no mínimo $5 \mathrm{~kg}$ do fruto e no máximo $15 \mathrm{~kg}$, bem como pagar uma taxa mínima estabelecida pela associação, e/ou doar 01 litro da polpa que, posteriormente, é utilizada em benefício da comunidade local nos eventos e nas festas organizadas em diferentes épocas do ano.

As folhas destinadas ao artesanato são escolhidas e separadas de acordo com a largura e o comprimento dos folíolos, sendo vetada a presença de fungos, caracterizada pelos extrativistas como "ferrugem". Pois, segundo os extrativistas/artesãos, o fungo compromete as folhas rapidamente e todo o trabalho manual desenvolvido por diferentes etapas e longas horas de trabalho, embora sejam reaproveitados apenas os folíolos em boas condições para o uso em diferentes técnicas, ainda que apresentem, parcialmente, lesões e/ou manchas (Figura 08).

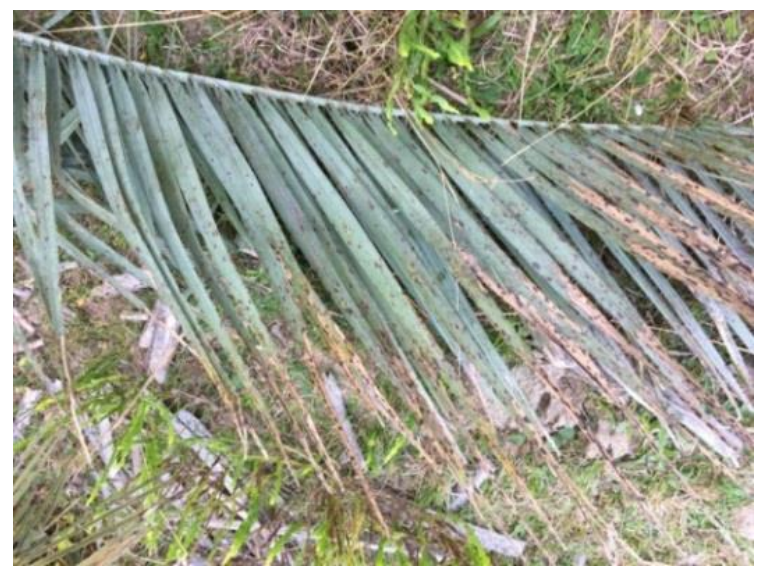

Figura 08: Fungo identificado na folha de butiazeiro, caracterizado pelos extrativistas como "ferrugem" (Fonte: AUTOR, 2018). 
A fibra, separada após a despolpa do fruto, é mantida em recipientes com água até que se forme uma consistência homogênea, sendo esta, seguidamente, pressionada com as mãos sobre diferentes vasilhas descartáveis, utilizadas como moldes em diversos tipos de artesanatos (Figura 09).

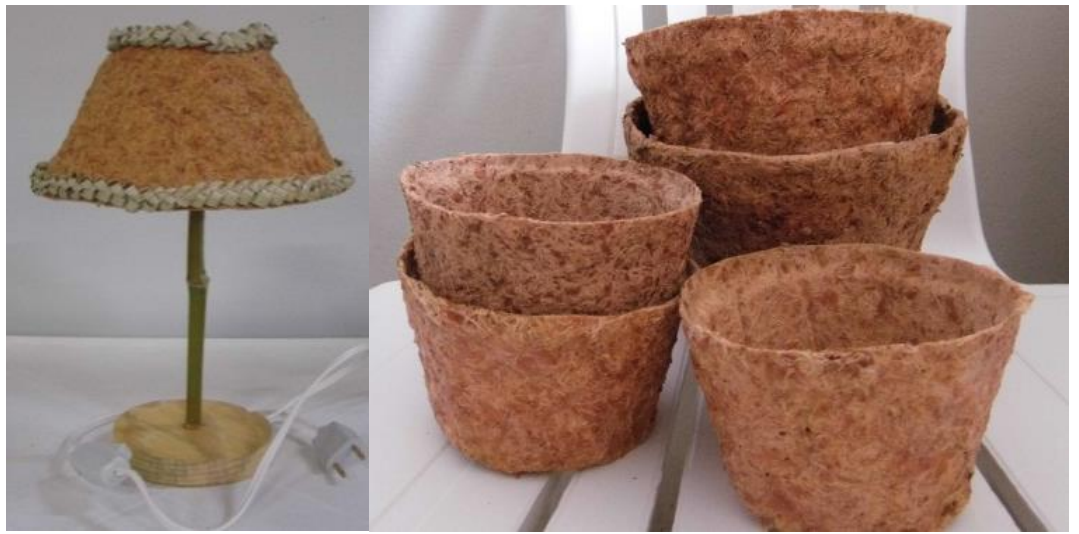

Figura 09: Artesanato produzido por meio da fibra do fruto do butiazeiro (Fonte: AUTOR, 2018).

Dos caroços, mais conhecidos como coquinhos, são criados diferentes tipos de enfeites, por exemplo, miniaturas da fauna do bioma Pampa. Cobertos por uma massa epóxi e fixados por um palito ou pedaço de arame, são produzidas peças alusivas à natureza, principalmente animais silvestes do estado do Rio Grande do Sul, em especial da fauna que habita o ecossistema dos butiazais, como o Sabiá, o Cardeal, o João de Barro, a Cutia, a Capivara e outros animais, alguns ameaçados de extinção (Figura 10).

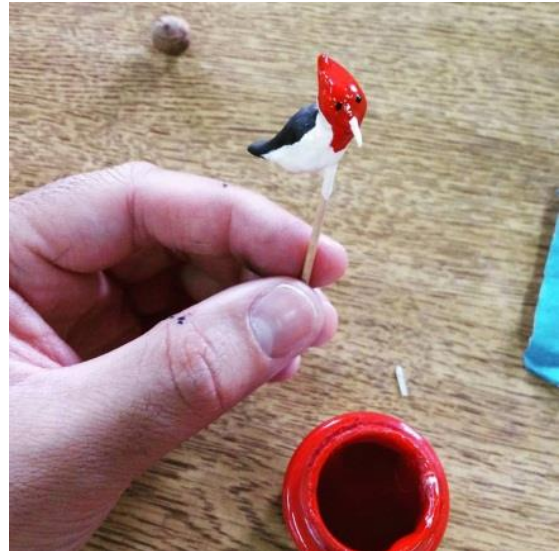

Figura 10: Representação da fauna silvestre que habita a região dos butiazais, feito com o coquinho de butiá (Fonte: AUTOR, 2018).

Percebe-se que muitas ações, envolvendo o uso pela conservação da espécie $B$. odorata, são promovidas por agricultores, extrativistas e artesãos pertencentes à APAFTAPES, embora outras iniciativas também tenham contribuído para a proteção de uma das maiores riquezas da região, seguidas de conhecimento cultural e desenvolvimento local. Com o turismo rural, recentemente empreendido por dois gestores ambientais, a população tapense e de municípios vizinhos estão podendo explorar a região dos butiazais de Tapes através de trilhas ecológicas/educativas, onde a ideia é agregar valores às propriedades rurais locais. No percurso, que pode variar de acordo com o grupo que solicita a caminhada, cada propriedade oferece algum serviço, ou seja, uma delas oferece um passeio guiado com veículo rural modificado, chamado de "Dindinho"; outra propriedade oferece o local para a alimentação com almoços campeiros, lanches e venda de produtos feitos pelos próprios produtores, como os sucos, licores, cucas, queijos, geleias, doce de leite e demais alimentos à base da polpa de butiá, bem como artesanatos; e outras, apenas disponibilizam o acesso à caminhada para a contemplação da paisagem. 


\section{CONCLUSÕES}

Neste estudo foram identificados 10 extrativistas e artesãos desempenhando ações locais como multiplicadores de saberes e educadores sociais na conservação pelo uso da palmeira $B$. odorata. Verifica-se que há uma adesão inicial à atividade do extrativismo no munícipio, em que emergem artesãs e artesãos com habilidades nas áreas da gastronomia, artesanato e entretenimento (turismo rural), sinalizando resultados positivos do Projeto da Rota dos Butiazais.

Conclui-se que as coletas e o manejo não diferem entre os participantes no ato do corte de folhas e cachos, visto que todos utilizam ferramentas semelhantes como o serrote e/ou facão, embora um dos extrativistas remova apenas alguns folíolos diretamente das folhas da palmeira para tramar e/ou trançar suas peças, sem que haja a necessidade de extraí-las por inteiro.

O mapeamento participativo das áreas de coleta registrou que cerca de 57\% do extrativismo ocorreram em propriedades privadas de amigos, familiares e colegas da APAFTAPES. Do total de matéria-prima extraída, cerca de $33 \%$ é destinada à produção de alimentos. Grande parte da produção à base da palmeira $B$. odorata é exposta e vendida no Mercado Público da cidade, onde os produtores, artesãos e extrativistas realizam feiras semanais, eventos e demais atividades articuladas ao meio rural à comunidade (cursos), em parceria com as instituições Embrapa, Emater local, Senar, Uergs e demais parceiros. As artesãs buscam ampliar os seus canais de comercialização.

Apesar dos participantes serem, em sua grande maioria, senhoras aposentadas e idosas com algumas limitações de saúde, elas desenvolvem ações sustentáveis que contribuem com o desenvolvimento rural a partir da conservação pelo uso dos recursos da biodiversidade local.

O setor primário - agricultura e pecuária - se destaca em Tapes, como o arroz irrigado por inundação, a soja, a acácia negra, os hortifrutigranjeiros, os laticínios, o milho, o morango e a pesca. A agricultura se restringe a um modelo de desenvolvimento convencional, em que o objetivo deixa de ser a produção de alimentos necessários para alimentar a população e passa a fazer parte de um mercado de commodities, que se desenvolve em direção contrária à da conservação da natureza e ao desenvolvimento rural sustentável. Com isso, consideramos que as ações desenvolvidas pelos extrativistas e artesãos de Tapes, incentivam, aos poucos, diferentes alternativas de desenvolvimento rural, que promovem a conservação dos ecossistemas, da biodiversidade e geração de renda complementar às famílias envolvidas.

\section{AGRADECIMENTOS}

Ao CNPq, pelo apoio financeiro em parceria com a Embrapa Clima Temperado, por meio do projeto "A Rota dos Butiazais no Bioma Pampa: conectando pessoas e ecossistemas para a conservação e o uso sustentável da biodiversidade", processo 441493/2017-3. À Universidade Estadual do Rio Grande do Sul e aos extrativistas/artesãos que contribuíram com este estudo e com o fortalecimento, em rede, da Rota Internacional dos Butiazais em Tapes.

\section{REFERÊNCIAS}

ALMEIDA, J. Da ideologia do progresso à ideia de desenvolvimento (rural) sustentável. In: ALMEIDA, J.; NAVARRO, Z. Reconstruindo a agricultura: ideias e ideais na perspectiva do desenvolvimento rural sustentável. 3. ed. Porto Alegre: UFRGS, 2009. p. 33-55.

BARBIERI, R. L. et al. Vida no Butiazal. Brasília, DF: Embrapa, 2015.

BARBIERI, R. L. et al. Conservação e uso sustentável de Butia odorata na região do Litoral Médio do Rio Grande do Sul. Natureza em Revista, Porto Alegre, p. 8-15, 2016.

BARBIERI, R. L. A Rota dos butiazais no bioma Pampa: conectando pessoas e ecossistemas para a conservação e uso sustentável da biodiversidade. Pelotas, RS: Embrapa Clima Temperado, 2017. (Projeto não publicado).

BECKER, F. G.; RAMOS, R. A.; MOURA, L. de A. (org.). Biodiversidade: regiões da Lagoa do Casamento e dos butiazais de Tapes, planície costeira do Rio Grande do Sul. Brasília, DF: MMA: FZRS, 2006.

BERTOLDI, M. R.; BARON, L. Solidariedades entre a sociobiodiversidade e o desenvolvimento sustentável. Publica Direto. Disponível em: <http://www.publicadireito.com.br/artigos/?cod=7c13a125a1257624>. Acesso em: 07 maio 2018.

BRASIL. Ministério do Desenvolvimento Agrário. Secretaria de Desenvolvimento Territorial no RS. Plano Territorial de Desenvolvimento Rural Sustentável - PTDRS: Território Centro-Sul. [S. 1.]: MDA: Colegiado Territorial RS, [2008?]. 
BRASIL. Lei n. 11.947, de 16 de jun. de 2009. Dispõe sobre o atendimento da alimentação escolar e do Programa Dinheiro Direto na Escola aos alunos da educação básica. Brasília, DF, jun. 2009.

BRASIL. Ministério do Meio Ambiente. Portaria Interministerial $n^{\circ}$. 163, de 11 de maio de 2016. Diário Oficial da União: seção 1, Brasília, DF, n. 94, p. 58-60, 18 maio 2016. Disponível em: <https://www.mma.gov.br/images/noticias_arquivos/pdf/sociobio.pdf>. Acesso em: 22 ago. 2020.

CAMPOS-JUNIOR, J. L. S. Extrativismo do Butiá no município de Tapes/RS: conservação pelo uso como alternativa para o desenvolvimento rural sustentável. 2018. Trabalho de Conclusão de Curso (Bacharelado em Gestão Ambiental) - Universidade Estadual do Rio Grande do Sul, Tapes, 2018.

COELHO-DE-SOUZA, G. Extrativismo em área de Reserva da Biosfera da Mata Atlântica no Rio Grande do Sul: um estudo etnobiológico em Maquiné. 2003, iii, 202 f. Tese (Doutorado em Botânica) Programa de Pós Graduação em Botânica, Universidade Federal do Rio Grande do Sul, Porto Alegre, RS, 2003.

COELHO-DE-SOUZA, G. et al. Sociobiodiversidade, soberania e segurança alimentar e nutricional: uma análise da governança do butiá. In: ENCONTRO INTERNACIONAL DA ROTA DOS BUTIAZAIS, 2, 2018, Pelotas. Anais.... Porto Alegre, RS: Embrapa Clima Temperado: UFRGS, 2018. p. 78-84.

CORREIA, D. et al. Etnobiologia Etnoecologia: pessoas \& natureza na América Latina. São Paulo: Instituto de Biociências, 2010.

DAL SOGLIO, F. K. Desenvolvimento, agricultura e agroecologia: qual a ligação? In: GERRA, G. A. D.; WAQUIL, P. D. (Org.). Desenvolvimento rural sustentável no Norte e Sul do Brasil. Belém: Paka-Tatu. 2013.

GEYMONAT, G.; ROCHA, N. Butia: ecosistema único en el mundo. Castillos, Rocha, Uruguay: Casa Ambiental, 2009

GRABHER, C. A governança e a sustentabilidade do extrativismo do jaborandi na Amazônia e transição para o cerrado e a caatinga. 2015. Dissertação (Mestrado em Desenvolvimento Rural) - Faculdade de Ciências Econômicas, Universidade Federal do Rio Grande do Sul. Porto Alegre, RS, 2015.

IBGE Cidades. Rio Grande do Sul. Tapes. Censo 2010. Disponível em: <https://cidades.ibge.gov.br/brasil/rs/tapes/panorama>. Acesso em: 02 set 2020.

MARCHI, M. M.; BARBIERI, R. L.; SOSINSKI JÚNIOR, Ê. E. Recursos genéticos e a conservação in situ de ecossistemas de butiazais no Sul do Brasil. Revista RG News, [S.1], v. 5, n. 1, p. 1-4, 2019.

MARCONI, M. de A.; LAKATOS, E. M. Fundamentos de metodologia científica. 7. ed. São Paulo: Atlas, 2010

MARCONI, M. de A.; LAKATOS, E. M. Fundamentos de metodologia científica. 6. ed. São Paulo: Atlas, 2011

MUNHOZ, E. Biodiversidade na região do butiazal de Tapes: desafios e possibilidades para a conservação e o uso sustentável. 2017. Trabalho de Conclusão de Curso (Bacharelado em Gestão Ambiental) Universidade Estadual do Rio Grande do Sul, Tapes, 2017.

PACHECO, F. T. Micro Habitats de regeneração do Butia odorata na região dos butiazais de Tapes/RS. 2017. Trabalho de Conclusão de Curso (Bacharelado em Gestão Ambiental) - Universidade Estadual do Rio Grande do Sul, Tapes, 2017.

PENROD, J. et al. A discussion of chain referral as a method of sampling hard-to-reach populations. Journal of Transcultural nursing, v. 14, n. 2, p. 100-107, 2003.

RIO GRANDE DO SUL. Secretaria do Ambiente e Desenvolvimento Sustentável. Certificação Ambiental Agroflorestal e Extrativista. Porto Alegre: Sema, 2017. Disponível em: $<$ http://www.sema.rs.gov.br/certificacao-ambiental-agroflorestal-e-extrativista>. Acesso em: 29 jun 2018.

RIVAS, M; BARBIERI, R. L. Boas práticas de manejo para o extrativismo sustentável do butiá. Pelotas: Embrapa Clima Temperado, 2014.

ROSSATO, M.; BARBIERI, R.L. Estudo etnobotânico de palmeiras do Rio Grande do Sul. Revista Brasileira de Agroecologia, v. 2, n. 1, 2007.

SCHNEIDER, S. Território, Ruralidade e Desenvolvimento. In: VELÁSQUEZ LOZANO, F.; MEDINA, J.

G. F. (eds.). Las configuraciones de los territorios rurales en el siglo XXI. Bogotá: Editorial Pontifícia Universidad Javeriana, 2009, v. 1, p. 67-108.

SCHWARTZ, E. et al. Avaliação de populações de Butia Capitata de Santa Vitória do Palmar. Pelotas/RS, 2009.

SILVA, S. C. C. DA. Análise ambiental integrada da paisagem no município de Tapes (RS), Brasil, como suporte ao gerenciamento costeiro. 2018. Tese (Doutorado em Geociências) Universidade Federal do Rio Grande do Sul, Porto Alegre, RS, 2018.

SOARES, K. P. et al. Palmeiras (Arecaceae) no Rio Grande do Sul, Brasil. Rodriguésia, v. 65, p. 113-139, 2014.

SOSINSKI, E. et al. Manejo conservativo: bases para a sustentabilidade dos Butiazais. Boletim de Pesquisa e Desenvolvimento. Pelotas: Embrapa Clima Temperado, 2015. 